\title{
A Study of Clinical and Laboratory Picture of Acute Tramadol Toxicity in Damietta Governorate
}

\author{
Mohammed A. Nasr ${ }^{1}$, Sherif Fahmy Mahmoud ${ }^{2}$, Mostafa A.Mohammed ${ }^{1}$, \\ Hesham S. Abd El- samie ${ }^{3}$
}

\begin{tabular}{|c|c|}
\hline & ABSTRACT \\
\hline $\begin{array}{l}\text { KEYWORDS } \\
\text { Tramadol, } \\
\text { HPLC, } \\
\text { Seizures, } \\
\text { Biochemical analysis. }\end{array}$ & $\begin{array}{l}\text { Increased rate of seizures and respiratory complications due to tramadol } \\
\text { poisoning have been observed, even with first time of tramadol intake. So, the } \\
\text { present work was used to investigate the clinical manifestations and laboratory } \\
\text { investigations of acute tramadol toxicity and the correlation between toxic tramadol } \\
\text { manifestations and blood tramadol level and laboratory parameters. A study was } \\
\text { performed on } 100 \text { patients (80 males and } 20 \text { females) acutely intoxicated with } \\
\text { tramadol, admitted to toxicology unit of Al-Azhar University Hospital (New } \\
\text { Damietta) in the period from January to December } 2017 \text {. Informed consent, urine } \\
\text { sample was collected and } 10 \mathrm{~mL} \text { of blood was separated and used for extraction of } \\
\text { tramadol residues by using a high-performance liquid chromatography (HPLC) and } \\
\text { other blood samples were stored at-8 Cor routine investigations. Then a detailed } \\
\text { clinical examination was done to all patients. Generally, the frequency of seizures } \\
\text { was (46 \%) with acute tramadol poisoning. There was no correlation between blood } \\
\text { tramadol level and toxic manifestations of tramadol poisoning. So, the frequency of } \\
\text { seizures and toxic manifestations are not dosed dependent. Cannabis was the most } \\
\text { common co-ingested drugs and adult males were more commonly affected by } \\
\text { tramadol poisoning. It is recommended that the drug abuse problem must be treated } \\
\text { at the level of community problems in order to minimize medical emergencies related } \\
\text { to acute tramadol overdose occurring mostly by addiction and further studies should } \\
\text { be proposed to extend our knowledge about relationships between sex and seizures } \\
\text { among tramadol intoxicated patients }\end{array}$ \\
\hline
\end{tabular}

\section{Introduction}

Tramadol is an opioid used for management of moderate to severe pains. It has been legally used for pain treatment since 1980 in some nations and became the most

(1) Forensic Medicine and Clinical Toxicology
Department, Faculty of Medicine, Al-Azhar
University (Damietta).
(2) Forensic Medicine and Clinical Toxicology
Department, Faculty of Medicine, Al-Azhar (Cairo)
(3) Clinical Pathology Department, Faculty of Medicine,
Al-Azhar University (Damietta).

prescribed opioid allover the world (Loughrey et al., 2003).

Tramadol exerts its action by weak binding to the $\mu$-opioid receptor and inhibiting reuptake of serotonin and norepinephrine (Shadnia et al., 2008).

The mainstream of the pain-killing action of tramadol may be a result of non-opioid characters through central monoaminergic pathways. Oral route is the most frequent route of administration of tramadol (Taghaddosinejad et al., 2011). 
Tramadol is addictive and may be abused by young adults. Tramadol therapeutic dose is $50 \mathrm{mg}$ orally compared to $50-100 \mathrm{mg}$ parentrally and $100 \mathrm{mg}$ in case of rectal administration, doses of $500-800 \mathrm{mg}$ are toxic and estimated lethal dose is between $3-5 \mathrm{gm}$ (Chandrasekaran et al., 2007). The most common effects of tramadol toxicity include nausea, vomiting, depression of central nervous system, tachyarrhythmia, cardio-respiratory depression, and convulsions. However, there are some studies reported the likelihood of seizure induction even with therapeutic doses (Derakhshanfar et al., 2012). Overdose of tramadol is one of the most common causes of admissions to the hospital due to tramadol toxicity (Talaie et al., 2009).

Seizures induced convulsions by tramadol were reported to be $15 \%$ to $35 \%$ (Kroenke et al., 2009).

Accurate mechanism of tramadolinduced seizure is not completely known. Trials indicate that in high concentrations, tramadol produces an inhibitory effect on gamma-aminobutyric acid (GABA) receptors (Rehni et al., 2008).

Inhibition of GABA receptors has been proposed to potentiate severity of convulsions in animal studies (Sun et al., 2007).

Also, inhibition of GABA receptors produced by tramadol can be secondary to its opioid receptor agonist action, and continuing this agonist action on opioid receptor has been confirmed to precipitate convulsions due to inhibition of GABA pathways (Rehni et al., 2008). Tramadol may possibly increase the convulsions risk in patients receiving other medications such as tricyclic anti-depressants, phenothiazines and selective serotonin reuptake inhibitors (Kroenke et al., 2009).

Tramadol - induced convulsions are controlled well by diazepam, but not respond to naloxone, and can be triggered by management with naloxone, at tramadol overdoses (Raffa and Stone, 2008).

The present study was designed to examine the clinical findings and laboratory tests of acute tramadol toxicity and correlations between toxic tramadol manifestations and plasma tramadol level and other laboratory parameters in toxicology unit, in Al-Azhar University Hospital (New Damietta) from the $1^{\text {st }}$ of January 2017 to the $1^{\text {st }}$ of December 2017.

\section{Patients and methods}

A cross-sectional study was performed on 100 patients (80 males and 20 females) acutely intoxicated with tramadol, referred and admitted to the toxicology unit of Al-Azhar University Hospital (New Damietta) in the period extending from January to December 2017.

Inclusion criteria included: definite history of tramadol intake alone or in combination with other drugs of abuse including toxicity either taken by subjects themselves or given by their relatives.

Exclusion criteria included: definite history of tramadol intake and negative parameters for qualitative detection of tramadol; history of chronic liver disease to keep away from the affection of liver functions; history of chronic renal disease to keep away from the affection of kidney functions, and pregnancy (Marco, 2007).

An informed consent was taken from every subject before inclusion in the study.

Data were collected from all patients including socio-demographic data (age, sex, occupation, marital status). In addition, clinical examination was done systematically and included vital data (respiratory rate, heart rate, 
blood pressure, body temperature and systemic examination according to Epstein et al., (2009) and Talley and O'Connor, (2013) for detection of any systemic abnormalities. Then, 3 milliliters of arterial blood were collected from each patient for measuring arterial blood gases, and 10 milliliters venous blood were collected from each patient for biochemical and toxicological analysis and urine samples were collected for urine toxicological screening of (benzodiazepine, cannabis, barbiturate, opiates, cocaine, and amphetamine).

Tramadol was detected in urine by immunoassay analysis as described by AlSaffar (2013), by Mgc240 micro genic automated clinical analyzers Tokyo boeki machinery LTD (Japan), while in blood, it was detected by HPLC analysis as described by Halling et al. (2008)

Tramadol (100ml $/ 2 \mathrm{ml} /$ ampoules $)$ were obtained from October Company, Cairo, Egypt. Potassium monobasic phosphate, sodium hydroxide, phosphoric acid, ethyl acetate (Analytical grade) and Acetonitrile (HPLC grade), were obtained from Electrosient Company, Cairo, Egypt.

\section{Statistical Analysis}

The collected data were organized, tabulated and statistically analyzed using SPSS software computer package version 16 (SPSS Inc. Chicago, IL). For quantitative data, all the values were expressed as the mean \pm standard deviation (SD) that the values $\mathrm{P}<0.05$ were considered statistically significant. For comparison between the two groups, the students ( $t$ ) test was used. For qualitative data, number and percent distribution were calculated and Chi-square test $(\chi 2)$ was used for comparison between two groups. Pearson's correlation coefficient was used to test the correlation between variables. $\mathrm{P}<0.05$ was considered to be statistically significant (Campbel and Machin, 2009).

\section{Results}

Social and demographic data (Table 1) shows: the mean age for cases in this study was $26.3 \pm 12.1$ years. Males represented the majority of cases $(80 \%)$ in comparison to females $(20 \%)$. Regarding route and mode of poisoning, all cases were intoxicated through the oral route. Tramadol overdose in addicts represented $58 \%$ of cases. Attempted suicides were evident in $36 \%$ of cases. Accidental ingestions were observed in $6 \%$ of cases.

Regarding co-ingested drugs, the most common co-ingested drugs with tramadol in this study were cannabis observed in $54 \%$ of cases followed by benzodiazepines detected in $10 \%$ of cases followed by opiates detected in $2 \%$ of cases.

Clinical manifestations in studied cases (Table 2): As regards clinical manifestation, the mean systolic blood pressure was $120 \pm 17$ $\mathrm{mmHg}$, the mean diastolic blood pressure was $80 \pm 11 \mathrm{mmHg}$, the mean temperature was $36.12 \pm 1.06{ }^{\circ} \mathrm{C}$, the mean respiratory rate was $20.32 \pm 1.06 \mathrm{rate} / \mathrm{min}$ and the mean pulse rate was $96 \pm 19$ among the studied cases in this study.

As regards the general manifestations, $16 \%$ of cases manifested with pallor and $4 \%$ of cases manifested with sweating. Concerning gastrointestinal manifestations, $14 \%$ of cases complained of vomiting and $4 \%$ of cases complained of abdominal pain. Respiratory system revealed that $42 \%$ had respiratory failure, $2 \%$ had severe hypoxemia and no case manifested with non-cardiogenic pulmonary edema. The neurological manifestations were 
$46 \%$ of cases manifested with seizures, $2 \%$ manifested with hallucinations, $6 \%$ manifested with agitation, 38\% manifested with drowsiness and $8 \%$ manifested with coma.

Regarding examination of pupils in cases of this study with respect to size and reactivity to light, normal sized reactive, miotic reactive, dilated fixed, dilated reactive, pinpoint and miotic reactive pupils were present in 94\%, $0 \%, 0 \%, 2 \%, 0 \%$ and $4 \%$ of cases respectively.

There was a non-significant correlation between tramadol blood levels and vital signs either pulse rate, systolic blood pressure, diastolic blood pressure temperature and the respiratory rate among cases in this study (Table 3).

Table (4) showed that blood tramadol levels was $(614 \pm 223 \mathrm{ng} / \mathrm{ml})$, arterial blood gases $(\mathrm{PH}, \mathrm{HCO} 3$ and $\mathrm{PaCO} 2)$ were $(7.42 \pm$ $0.0995,23.5 \pm 4.9$ and $43.3 \pm 7.5)$ respectively and within normal range of serum glucose as it was $(107.2 \pm 45.5 \mathrm{mg} / \mathrm{dL})$, AST levels were $(11.7 \pm 7.5 \mathrm{IU} / \mathrm{L})$, ALT levels were $(7.6 \pm 5.8$ $\mathrm{IU} / \mathrm{L})$ urea levels was $(26.6 \pm 12.0 \mathrm{mg} / \mathrm{dL})$, creatinine levels were $(1.1 \pm 0.4 \mathrm{mg} / \mathrm{dL})$.

Correlation between blood tramadol levels and biochemical markers Table (5) shows that there was no significant correlation between tramadol blood levels and fasting blood sugar, AST, serum creatinine. There was no significant correlation between tramadol blood levels and ALT, blood urea and ABG (blood $\mathrm{pH}$ and $\mathrm{HCO} 3$ ).

Correlation between changes in blood tramadol levels and seizures among the studied cases: Table (6) shows that there was a nonsignificant correlation between tramadol blood levels and occurrence of seizures among cases in this study.

Table (1): Distribution of the demographic and social data in studied cases.

\begin{tabular}{|l|l|c|}
\hline \multicolumn{2}{|c|}{ Studied parameters } & n (\%) \\
\hline \multirow{4}{*}{ Mode of poisoning } & Addict & $58(58.0 \%)$ \\
\cline { 2 - 3 } & Suicidal & $36(36.0 \%)$ \\
\cline { 2 - 3 } & Accidental & $6(6.0 \%)$ \\
\cline { 2 - 3 } & Homicidal & $0(0.0 \%)$ \\
\hline \multirow{4}{*}{ Co-ingested drugs } & Absent & $40(40.0 \%)$ \\
\cline { 2 - 3 } & Cannabis & $54(54.0 \%)$ \\
\cline { 2 - 3 } & Benzodiazepines & $10(10.0 \%)$ \\
\cline { 2 - 3 } & Opiates & $2(2.0 \%)$ \\
\hline
\end{tabular}

n: number, \%: percentage. 
Table (2): Clinical manifestations in studied cases $(\mathrm{n}=100)$

\begin{tabular}{|c|c|c|}
\hline \multicolumn{2}{|r|}{ Studied Parameters } & mean \pm SD \\
\hline \multirow{5}{*}{ Vital sign } & Systolic blood pressure & $120 \pm 17 \mathrm{mmHg}$ \\
\hline & Diastolic blood pressure & $80 \pm 11 \mathrm{mmHg}$ \\
\hline & Temperature ( $\mathrm{C}$ ) & $36.12 \pm 1.06$ \\
\hline & Respiratory rate/min & $20.32 \pm 1.06$ \\
\hline & Heart rate beats $/ \mathrm{min}$ & $96 \pm 19 \mathrm{~b} / \mathrm{m}$ \\
\hline \multicolumn{2}{|r|}{ Studied parameters } & n (\%) \\
\hline \multirow{2}{*}{$\begin{array}{l}\text { General } \\
\text { manifestations }\end{array}$} & Pallor & $16(16.0 \%)$ \\
\hline & Sweating & $4(4.0 \%)$ \\
\hline \multirow{2}{*}{$\begin{array}{l}\text { GIT } \\
\text { manifestations }\end{array}$} & Vomiting & $14(14.0 \%)$ \\
\hline & Abdominal pain & $4(4.0 \%)$ \\
\hline \multirow{3}{*}{$\begin{array}{l}\text { Respiratory } \\
\text { manifestations }\end{array}$} & Respiratory failure & $42(42.0 \%)$ \\
\hline & Severe hypoxemia & $2(2.0 \%)$ \\
\hline & Non cardiogenic pulmonary edema & $0(0.0 \%)$ \\
\hline \multirow{11}{*}{$\begin{array}{l}\text { Central nervous } \\
\text { system } \\
\text { manifestations }\end{array}$} & Seizures & $46(46 \%)$ \\
\hline & Hallucinations & $2(2.0 \%)$ \\
\hline & Agitation & $6(6 \%)$ \\
\hline & Drowsiness & $38(38 \%)$ \\
\hline & Coma & $8(8 \%)$ \\
\hline & Normal sized reactive pupils & $94(94.0 \%)$ \\
\hline & Miotic irreactive pupils & $0(0.0 \%)$ \\
\hline & Dilated fixed pupils & $0(0.0 \%)$ \\
\hline & Dilated reactive pupils & $2(2.0 \%)$ \\
\hline & Pin point pupils & $0(0.0 \%)$ \\
\hline & Miotic reactive pupils & $4(4.0 \%)$ \\
\hline
\end{tabular}

n: number, \%: percentage, SD: standard deviation.

Table (3): Correlation between vital signs and blood tramadol levels among the studied cases.

\begin{tabular}{|l|c|c|c|c|c|c|}
\hline Parameters & & $\begin{array}{c}\text { Pulse } \\
\text { rate }\end{array}$ & $\begin{array}{c}\text { Systolic blood } \\
\text { pressure }\end{array}$ & $\begin{array}{c}\text { Diastolic blood } \\
\text { pressure }\end{array}$ & Temperature & $\begin{array}{c}\text { Respiratory } \\
\text { rate }\end{array}$ \\
\hline $\begin{array}{l}\text { Tramadol } \\
\text { blood level } \\
\begin{array}{l}\text { Mean }= \\
614.19 \mathrm{ng} / \mathrm{ml}\end{array}\end{array}$ & $\mathrm{r}$ & 0.218 & -0.199 & -0.1728 & -0.1728 & 0.1728 \\
\cline { 2 - 7 } & $\mathrm{p}$ & 0.439 & 0.119 & 0.615 & 0.615 & 0.215 \\
\cline { 2 - 7 } & Mean & 95.06 & 120.1 & 79.6 & 79.6 & 90.6 \\
\hline
\end{tabular}

r: correlation coefficient. 
Table (4): Laboratory investigations in the studied cases.

\begin{tabular}{|c|c|c|c|}
\hline \multicolumn{2}{|c|}{ Parameter } & Mean \pm SD & Range \\
\hline \multicolumn{2}{|c|}{ Tramadol blood levels (ng/ml) } & $614 \pm 223$ & $102.4-1000$ \\
\hline \multirow{3}{*}{ Arterial blood gases } & $\mathrm{pH}$ & $7.42 \pm 0.0995$ & $6.91-7.33$ \\
\hline & $\mathrm{HCO} 3(\mathrm{mmol} / \mathrm{L})$ & $23.5 \pm 4.9$ & $6.4-31.3$ \\
\hline & $\mathrm{PaCO} 2$ (mmHg) & $43.3 \pm 7.5$ & $29.2-60$ \\
\hline \multicolumn{2}{|l|}{ Glucose (mg/dl) } & $107.2 \pm 36.5$ & $63-294$ \\
\hline \multicolumn{2}{|c|}{ Aspartate aminotransferase AST (IU/L) } & $11.7 \pm 10.9$ & $4-72$ \\
\hline \multicolumn{2}{|c|}{ Alanine aminotransferase ALT (IU/L) } & $7.7 \pm 8.7$ & $3-49$ \\
\hline \multicolumn{2}{|l|}{ Urea (mg/dl) } & $26.6 \pm 6.8$ & $10-45$ \\
\hline \multicolumn{2}{|l|}{ Creatinine (mg/dl) } & $1.1 \pm .2$ & $0.5-1.7$ \\
\hline
\end{tabular}

n: number, SD: standard deviation

Table (5): Correlation between blood tramadol levels and biochemical markers.

\begin{tabular}{|c|c|c|c|}
\hline \multirow{2}{*}{\multicolumn{2}{|c|}{ Parameter }} & \multicolumn{2}{|c|}{ Study group $(n=100)$} \\
\hline & & $\mathbf{r}$ & $\mathbf{p}$ \\
\hline \multicolumn{2}{|c|}{ Fasting blood sugar (mg/dL) } & 0.116 & 0.21 \\
\hline \multirow{2}{*}{ Liver enzymes } & Aspartate aminotransferase ALT (mg/dL) & -0.254 & -0.02 \\
\hline & Alanine aminotransferase AST (mg/dL) & 0.075 & 0.884 \\
\hline \multirow{2}{*}{$\begin{array}{l}\text { Kidney } \\
\text { enzymes }\end{array}$} & Creatinine (mg/dL) & 0.270 & 0.058 \\
\hline & Urea $(\mathrm{mg} / \mathrm{dL})$ & -0.232 & 0.105 \\
\hline \multirow{2}{*}{ ABG } & Blood PH & -0.158 & 0.272 \\
\hline & $\mathrm{HCO} 3(\mathrm{meq} / \mathrm{L})$ & -0.262 & 0.066 \\
\hline
\end{tabular}

ABG:arterial blood gases

Table (6): Correlation between blood tramadol levels and seizures among the studied cases.

\begin{tabular}{|l|c|c|c|c|}
\hline $\begin{array}{c}\text { Group of } \\
\text { seizures }\end{array}$ & $\%$ & $\begin{array}{c}\text { Mean of tramadol blood levels } \\
(\text { mean } \pm \text { SD) }\end{array}$ & Mann-Whitney & p-value \\
\hline Yes & $46 \%$ & $621.6 \pm 170.4$ & 310 & 0.992 \\
\hline No & $54 \%$ & $607.9 \pm 262.99$ & \multirow{2}{*}{. } & \\
\hline
\end{tabular}

SD: standard deviation 


\section{Discussion}

In this study, the mean age of cases was $26.3 \pm 12.1$ years and this explained that the young people represent the majority of cases. This is in agreement with Afshari et al. (2008) and Ahmad and Reza (2010).

In this study, males represented the majority of cases. Petramfar and Haghighi (2010) justified the high tramadol abuse among males to its alleged improvement of sexual performance.

In this study, all cases were intoxicated by ingestion as it is most prevalent and easily accessible.

According to this study, majority of cases of tramadol overdose were addicts and attempted suicide. This coincides with Marwa (2010). However, in controversy to present study, many researchers reported that the causes for the exposures included mostly suicide attempts (Persson and Sjöberg, 2008, Shadnia et al., 2008).

In this work, the most common coingested drugs with tramadol were cannabis followed by benzodiazepines and opiates. The widespread cannabis abuse was documented in previous studies reaching $18 \%$ of drivers. It has been explained as well by the WHO, reported that cannabis abusers are found in all age groups and social strata. Special target groups are adult smokers in rural areas of Africa and Eastern Mediterranean (Yassaa et al., 2009). On the other hand, Fariba et al. (2010) noticed that the most common coingested drugs were opioids.

Results of blood pressure in the present work were comparable to those observed by Shadnia et al. (2008) and Ahmad and Reza (2010). They that reported tramadol seems to offer advantages due to its minor cardiovascular side effects.
In the current study, as regards the neurological manifestations, most of cases manifested with seizures, followed by drowsiness and coma. On the contrary, Ahmad and Reza (2010) showed that $87 \%$ of cases were comatose and $13 \%$ were suffering from seizures. Although the typical symptoms of opiates agonist overdose include coma as the expected symptoms of tramadol overdose, yet the presentation with drowsiness in $38 \%$, agitation in $6 \%$ and seizures in $46 \%$ confirm the multiple actions of tramadol on the CNS. Concerning seizures, nearly different results were obtained by Persson and Sjöberg (2008).

Most of the cases (61.54\%) with disturbed conscious levels were found by Shadnia et al. (2008) in coma grade I according to Reed's classification, $23.07 \%$ in coma grade II, $11.54 \%$ in coma grade III and $3.85 \%$ in coma grade IV. This can be explained by the weak-binding capacity of tramadol to $\mu$-opioid receptors and its low risk for CNS depression as compared with other traditional opioids.

As regards, coma, seizures, agitation, and hallucination, Marquardt et al. (2005) noticed nearly similar results. Shadnia et al. (2008) noticed seizures in $35.1 \%$ who were related this finding to the high doses of tramadol, except in one case, who ingested $300 \mathrm{mg}$ of tramadol.

Seizures in a higher percent in this study $(46 \%)$ are attributed to the prominent action of tramadol in norepinephrine reuptake inhibition, which is as well responsible for agitation. Mazor et al. (2008) reported unusual neuro-logical presentation in a case of an 8-week-old boy who exhibited an altered mental status and dystonia while the other case of a 10-month-old girl exhibited seizures.

This study revealed that there was no significant correlation between tramadol blood levels and seizures. Petramfar and Haghighi (2010) showed that tramadol provoked seizures not only in supratherapeutic doses but also in the 
recommended therapeutic doses even as low as $50 \mathrm{mg}$. As a matter of fact, in that study, more than $80 \%$ of patients had a seizure after ingesting recommended doses of tramadol. Shadnia et al. (2008) in a case report described 2 generalized seizures in a nonepileptic 17-year-old patient following oral intake of 200-250 mg of tramadol.

On the contrary, Talaie et al. (2009) reported that the potential of tramadol to cause seizures seems to be dose-dependent. At clinically relevant doses, tramadol has been shown to slightly suppress the severity of seizures but at relatively higher doses, tramadol has paradoxically been proven to induce seizures.

In this study most of tramadol overdose patients could not be properly recognized due to the inaccessibility to a confident history; the patients being either drowsy, comatose or in a state of seizures with postictal confusion and disorientation/ or coma. Another factor suggesting the poor orientation of dose to the precipitation of seizures seems the coingested drugs (like Benzodiazepine) that would abort seizures. The third reason that seems to justify the non-correlation of dose and seizures is the sensitization of the individual to the norepinephrine reuptake inhibition that would provide inter-individual variability.

In the current study, examining the pupils revealed that most of cases were normal sized reactive. Ahmad and Reza (2010) noticed that unlike other opioid overdoses, some patients who were referred with mydriasis are more prone to seizures. Mydriasis, therefore, may be useful as a predictive factor for seizures in tramadol overdose. Also, serotonin syndrome can also cause mydriasis (Radomski et al., 2000). However, Shadnia et al. (2008) observed miosis in $16.8 \%$ and mydriasis in $4.4 \%$.
This study revealed that there was no significant correlation between tramadol blood levels and either of serum glucose, AST, ALT, urea or creatinine. This is in accordance with Kung and $\mathrm{Ng}$ (2007) who reported normal liver and renal function tests. In contrary to Gheshlaghi et al. (2009) who reported that BUN/Creatinine, blood sodium and potassium, creatinine phosphor-kinase, AST, and ALT were within the normal range. In addition, Daubin et al. (2007) revealed normal laboratory parameters mentioned above except for high serum creatinine, glucose, and creatine kinase. However, in controversy to this study, Ahmad and Reza (2010) showed higher mean levels for serum creatinine and glucose but lower mean levels for serum urea and creatine kinase-total.

In this study, the mean of plasma tramadol levels was $614 \pm 223 \mathrm{ng} / \mathrm{ml}$. Lewis et al. (2010) reported that whole blood tramadol concentrations obtained from 11 cases ranged from $81-2720 \mathrm{ng} / \mathrm{mL}$.

\section{Conclusion}

Adult males were more commonly affected by tramadol poisoning. The only route of intoxication was orally and addiction represents the most common mode of poisoning. Cannabis was the most common co-ingested drugs. Seizures were the most common CNS manifestations followed by drowsiness and no correlation between blood levels of tramadol and occurrence of seizures. Normal sized reactive pupils were highly found followed by miotic reactive pupils. No change was found in laboratory parameters with tramadol poisoning and no correlation between the laboratory parameters and blood levels of tramadol. 


\section{References}

Afshari, R.; Tashakori, A.; Shakiba, A.H. (2008): "Tramadol overdose induced CPK rise, hemodynamic and electrocardio-graphic changes and seizure". Clin. Toxicol., 46:120-125.

Ahmad, T. and Reza, A. (2010): "Tramadol overdose as a cause of serotonin syndrome: a case series". Clinical Toxicology, 48:337-341.

Al-Saffar, A. (2013): "Tramadol detection in urine by immunoassay analysis-". Ther. Drug Monit., 30: 71-75.

Campbel, M.J. and Machin, D. (2009): Statistical Inference. In: Medical Statistical: A Common Sense Approach, Campbel, M. J. and Machin, D. (Ed). John Wiley and Sons Chichester, New York, Brisbane, Toronto, Singapore, P.P. 69.

Chandrasekaran, D.; De Silva, P. and Dhatariya, K. (2007): "An uncommon presentation of a common drug overdose - the dangers of underestimating tramadol". Journal of Medical Sciences Research, 1:59-62.

Derakhshanfar, H.; Kalantari, Meibodi, M.; Kariman, H.; and Safari, S. (2012): "Substance abuse among drivers of motor vehicle collisions". Trauma Mon., 80-110.

Daubin, C.; Quentin, C.; Goullé, J.P.; Guillotin, D.; et al. (2007): "Refractory shock and asystole related to tramadol overdose". Clin. Toxicol. (Phila), 45: 961-964.

Epstein, O.; Perkin, G.D.; Cookson, J.; Watt, I.S., and Rakhit, R. (2009):
Clinical Examination. $4^{\text {th }}$ edition, Mosby, Philadelphia, P.P. 439.

Fariba, S.I..; Maryam, A.; Farzaneh, J. and Leila, B. (2010): "Morbidity: Tramadol current trends in tramadol-related fatalities, Tehran, Iran 2005-2008." Substance Use \& Misuse., 45:21622171.

Gheshlaghi, F.; Eizadi-Mood, N.; Fazel, K. and Behjati, M. (2009): "An unexpected sudden death by oral tramadol intoxication: a case not reported earlier". Iranian Journal of Toxicology, 2 (4): 293-297.

Halling, J.; Weihe, P.; and Brosen, K. (2008): "CYP2D6 polymorphism in relation to tramadol metabolism. A study of faroese patients", Ther. Drug Monit., 30: 271275.

Kroenke, K.; Krebs, E. and Bair, M. (2009): "Pharmaco-therapy of chronic pain: a synthesis of recommendations from systematic reviews". Gen. Hosp. Psychiatry, 31(3):206-219.

Kung, S. and Ng, M. (2007): "Serotonin syndrome with tramadol and dextromethorphan". Hong Kong Journal of Emergency Medicine, 14(1): 48-52.

Lewis, K.S. and Han, N.H. (2010): "Tramadol: a new centrally acting analgesic". American Journal of Health-System Pharmacy, 54(6): 643-652.

Loughrey, M.B.; Loughrey, C.M.; Johnston, S. et al. (2003): "Fatal hepatic failure following accidental tramadol overdose". Forensic Science International, 134: 232233.

Marco, C. A. (2007): "Impact of detailed informed consent on research subjects' participation: A prospective randomized 
trial". The Journal of Emergency Medicine, 34 (3): 269-275.

Marwa, M.F. (2010): "Some medicolegal aspects concerning tramadol abuse: The new Middle East youth plague 2010". Egyptian Journal of Forensic Sciences, 1(2): 99-102.

Mazor, S.S.; Feldman, K.W.; Sugar, N.F.; and Marcio, S. (2008): "Pediatric tramadol ingestion resulting in seizure like activity; a case series". Pediatric Emergency Care, 24(6): 381-386.

Marquardt, K.A.; Alsop, J.A. and Albertson, T.E. (2005): "Tramadol exposures reported to statewide poison control system". Ann. Pharmacother., 39: 1039-1044.

Persson, H. and Sjöberg, G. (2008): "Acute toxicity of tramadol - Analysis of 287 cases". Clinical Toxicology, 46(5): 398-401.

Petramfar, P. and Haghighi, A.B. (2010): "Tramadol induced seizure: Report of 106 patients". Iranian Red Crescent Medical Journal, 12(1): 49-51.

Radomski, J.W.; Dursun, S.M.; Reveley, M.A. and Kutcher, S.P. (2000): "An exploratory approach to the serotonin syndrome: an update of clinical phenomenology and revised diagnostic criteria". Med. Hypothesis, 55:218-224.

Raffa, R.B. and Stone, D.J. (2008): "Unexceptional seizure potential of tramadol or its enantiomers or metabolites in mice". J. Pharmacol. Exp. Ther., 325(2):500-506.
Rehni, A.K.; Singh, I. and Kumar, M. (2008): "Tramadol-induced seizurogenic effect: a possible role of opioid-dependent gamma-aminobutyric acid inhibitory pathway". Basic Clin. Pharmacol. Toxicol., 103(3):262-266.

Shadnia, S.; Soltaninejad, K.; Heydari, K.; Sasanian, G. and Abdollahi, M. (2008): "Tramadol intoxication: a review of 114 cases". Hum. Exp. Toxicol., 27(3):201205.

Sun, C.; Mtchedlishvili, Z.; Erisir, A. and Kapur, J. (2007): "Diminished neurosteroid sensitivity of synaptic inhibition and altered location of the alpha4 subunit of GABA (A) receptors in an animal model of epilepsy". J. Neurosci., 27(46):12641-12650.

Taghaddosinejad, F.; Mehrpour, O.; Afshari, R.; Seghatoleslami, A.; Abdollahi, M. and Dart, R. (2011): "Factors related to seizure of tramadol poisoning and its blood concentration". J. Med. Toxicol., 7:183-188.

Talley, N.J. and O'Connor, S. (2013): Clinical Examination. In: A Systematic Guide to Physical Diagnosis. $7^{\text {th }}$ edition, Elsevier Health Sciences, P.P. 21-57.

Talaie, H.; Panahandeh, R.; Fayaznouri, M.; Asadi, Z. and Abdollahi, $M$. (2009):"Dose-independent occurrence of seizure with tramadol". J. Med. Toxicol., 5(2):63-67.

Yassaa, H. A.; Abd El-Wahab, A.; Dawooda, M. and Shehatab M. (2009): "Risk factors for bango abuse in Upper Egypt". Environmental Toxicology and Pharmacology, 28: 397-402. 


\section{دراسة الصورة الإكلينيكية والمعملية للتسمم الحاد بعقار (الترامادول) في محافظة دمياط}

\section{محمد أحمد نصر'، شريف فهمي محمود'، مصطفى عبل المنعم محمد'، و هشام سمير عبدالسميع ‘}

(') قسم الطب الثرعي والسموم الإكلينيكية ـ كليه الطب - جامعة الأزهر (دمياط)

(") قسم الطب الثرعى والسموم الإكلينيكية ـ كلية الطب ـ جامعة الأزهر (القاهره)

("ّ) قسم الباثولوجيا الإكلينيكية ـ كليه الطب- جامعة الأزهر (دمياط)

لقد لـوحظ زيـادة في معدل حدوث النوبـات التشنجيه ومضاعفات الجهاز التنفسي نتيجـة التسمم بعقار

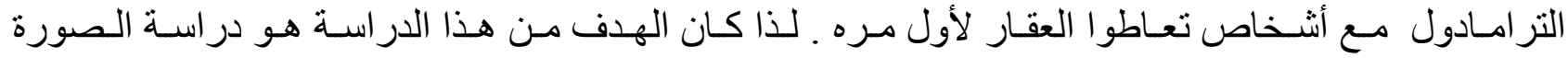

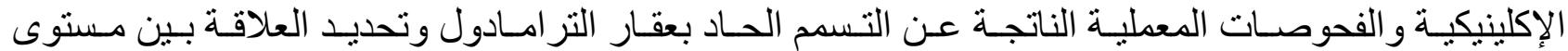
التر امادول فى الدم ومظاهر التسمم الإكلينيكية والفحوصات المعملية. تم عمل هذه الدر اسـة فى الفترة من يناير

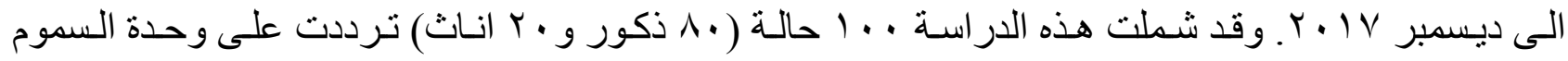
بمستشفى الأزهر الجامعي بدمياط الجديدة. تم اخذ المو افقة من الحالات عند وصولهم الى المستشفى. تم اخذ عينة

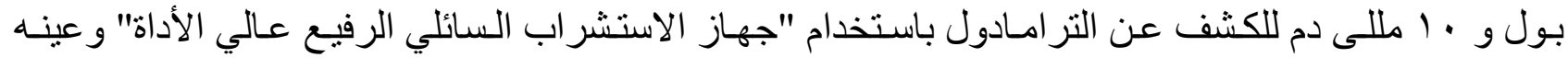

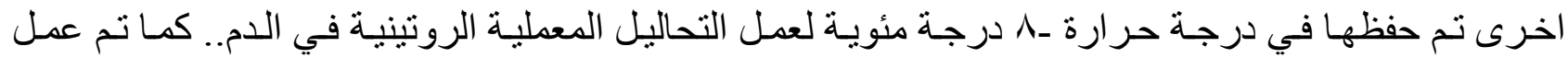
الفحص الإكلينيكي لهم ـ وقد أسفرت نتائج هذه الدر اسـة على أن معدل حدوث النوبـات الصر عية كان بنسبة

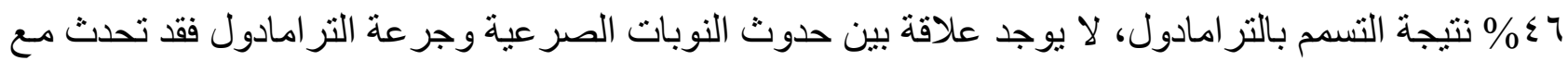
الجر عات العلاجية، كما أنه لا توجد علاقة بين حدوث النوبات الصر عية ومظاهر التسمم الأخرى وبين مستوى

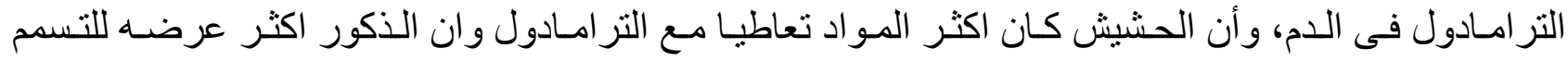

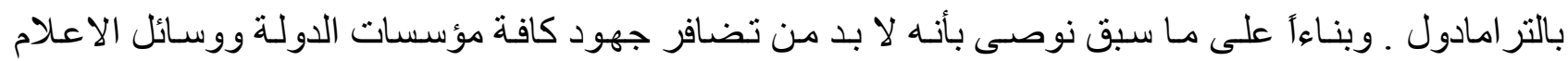

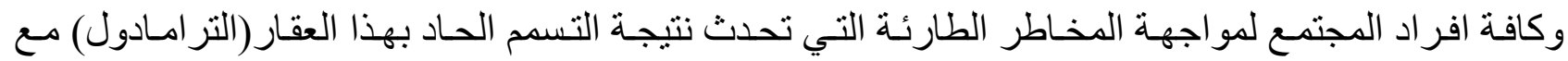
توضيح هذه المخاطر وذللك للحد من تناوله ، و لا بد من إيضاح حقيقة هامة وهى ان حدوث التشنجات الناتجة من

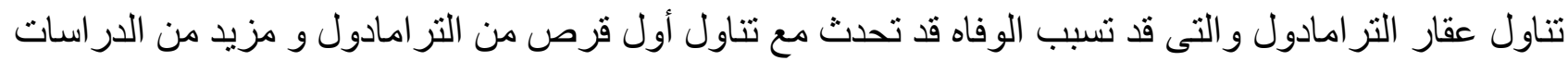

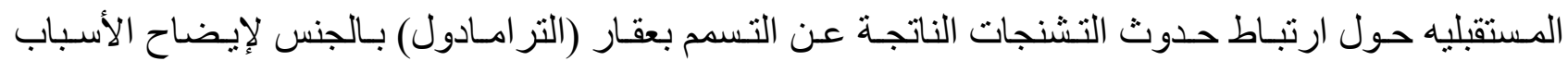
المسؤولة عن ذلك. 